\title{
Development of Niobium Microalloyed Steel for Railway Wheel with Pearlitic Bainitic Microstructure
}

\author{
Domingos José Minicucci $^{a} *^{\circledR}$, Solange Tamara Fonseca ${ }^{(\mathbb{D}}$, Renato Lyra Villas Boas ${ }^{c}$, \\ Hélio Goldenstein ${ }^{d}$, Paulo Roberto $\mathrm{Mei}^{b}$ \\ ${ }^{a}$ DJ Consulting, Botucatu, SP, Brasil \\ ${ }^{b}$ Universidade de Campinas, Campinas, SP, Brasil \\ ${ }^{c}$ MWL Brasil Rodas \& Eixos Ltda, Caçapava, SP, Brasil \\ ${ }^{d}$ Universidade de São Paulo, São Paulo, SP, Brasil
}

Received: December 29, 2018; Revised: November 2019; Accepted: November 25, 2019.

\begin{abstract}
Heavy haul transportation (load over 30 tons/axle), as well as the axle load, has been more and more used in Brazil and worldwide. The stress generated in the wheel-rail contact with loads up to 30 tons/axle is around $760 \mathrm{MPa}$, which causes premature wear and cracks of conventional wheels (AAR (Association of American Railroads) class C). Microalloyed wheels are fundamental on heavy haul transport, whose main function is to combine high hardness, ductility, and yield strength of the material in order to prevent shelling. The main purpose of this research is to develop a new microalloyed wheel steel with niobium addition that meets all the requirements of the AAR class D material with mixed microstructure composed of pearlite and bainite. The $0.71 \mathrm{C} / 0.020 \mathrm{Nb}$ steel developed in this study $(\mathrm{Nb}$ material) for railroad achieved the standards required for AAR class D in all mechanical properties, with fracture toughness higher than the usual vanadium microalloyed steel used in comparison. The Continuous Cooling Transformation (CCT) diagram showed the presence of bainite even at very low cooling rate, in the range between $0.3-2{ }^{\circ} \mathrm{C} / \mathrm{s}$. These cooling rates to form bainite are much lower than those observed in other steels with similar composition.
\end{abstract}

Keywords: Microalloyed railway wheel, niobium, heavy haul

\section{Introduction}

Brazil is the largest niobium producer in the world, and it has the biggest reserve of this element, as well; therefore, its increased use is desirable for the country. Brazil is also an important iron ore producer worldwide. Nowadays, the axle load on heavy haul transportation is 32 tons/axle, but the aim is it to achieve 35 or 40 tons/axle, like in Australia. One of the most common flaws of the wheels in operation for heavy haul transportation is shelling, which is defined as the loss of material because of rolling contact fatigue. Shelling starts on or below the surface on wheel tread, moving inwards toward the rim. It is a process of material loss from the wheel tread following the establishment of a fatigue crack network ${ }^{1}$ (figure 1). The repeated cyclic loading and unloading of the wheel tread together with the additional creep forces leads, eventually, to a local plastic deformation of the material through the process known as ratchetting. The solution to prevent shelling in the wheels is using steel with a higher resistance and yield limit associated with fatigue resistance.

In 2013, the AAR (Association of American Railroads) introduced a new class of wheels called $\mathrm{D}^{2}$ for heavy haul application, which has similar chemical composition of class $\mathrm{C}$, yet it is microalloyed with strong carbide-forming elements such as vanadium (V), $\mathrm{Nb}$, and molybdenum (Mo). The addition of microalloying elements is intended to improve the mechanical properties, reducing the wear and increasing the toughness and yield strength.

*e-mail: domingosminicucci@terra.com.br
The pearlite microstructures have been widely used in railway wheels and rails over the years, and since the beginning of their application there have been few modifications in their microstructure. Recent research has sought to reduce the interlamellar spacing and the size of the perlite colonies by micro addition of the carbide-forming alloying elements previously mentioned, as well as a combination of thermal and thermomechanical treatment routes ${ }^{3}$. Oliveira ${ }^{4}$ observed the benefit of $\mathrm{Nb}$ and Mo addition on the fatigue life of a class $C$ steel, although the microalloyed steel could not meet the requirements for AAR class D in terms of elongation on the tensile test.

The increase in mechanical resistance from pearlite microstructures has reached its limit, which makes it necessary to search for alternative microstructures for application in wheels and rails ${ }^{5}$. A few years ago, the development of steels with bainitic microstructure for wheels and rails (with a greater focus on rails) was required, which express higher values of mechanical strength, toughness, and wear resistance than those obtained by pearlitic microstructure ${ }^{6}$ and ${ }^{7}$.

The current microalloyed steels for railroad wheels use $\mathrm{V}$ with pearlitic microstructure, whose hardness is close to the limit for this application ${ }^{9}$. On the other hand, $\mathrm{V}$ is imported with high cost. Niobium acts as a controller for the grain size, which increases the strength and toughness by preventing edge dislocation ${ }^{10}$. Moreover, $\mathrm{Nb}$ delays austenite decomposition, increasing hardenability.

The multi-phase microstructures, like bainite and pearlite, demonstrated abrasion resistance more clearly. 


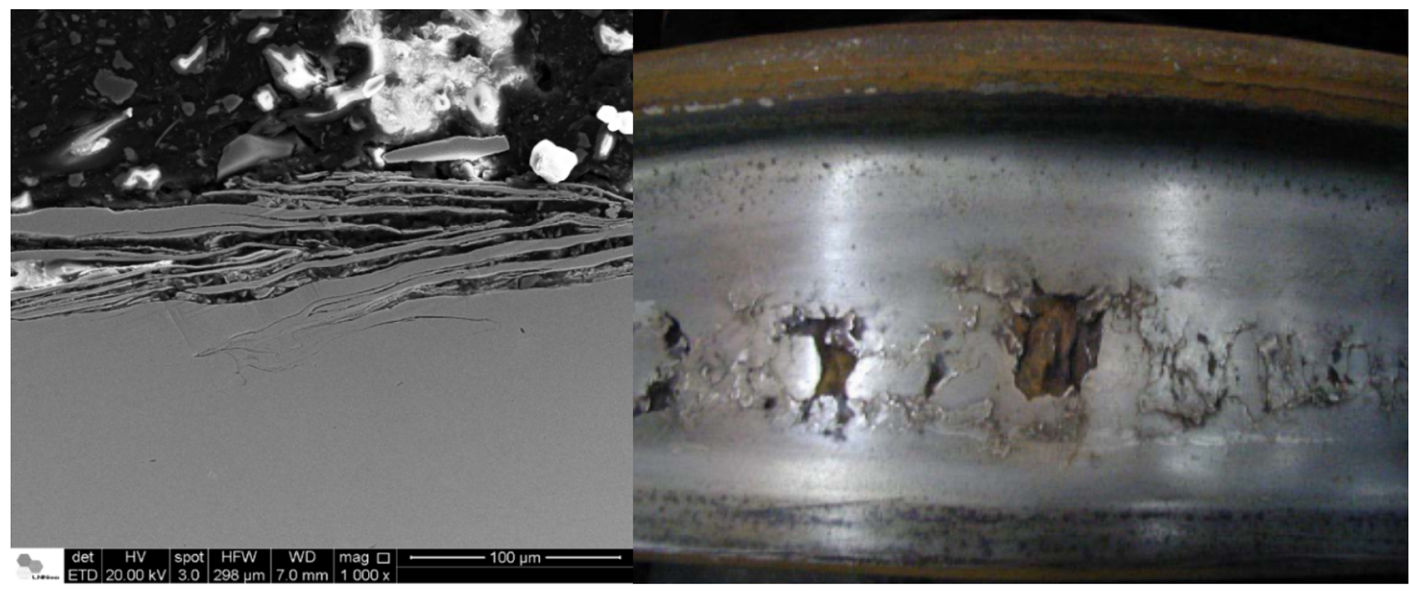

(a)

(b)

Figure 1. (A) Lamellar structure of cracks in the disk radial section of $7 \mathrm{~V}$ steel after 100,000 cycles. The broken material is detached forming debris flakes ${ }^{8}$. (B) Wheel tread with schelling (1).

The microstructure had a significant effect on the wear rate, showing that the combination of brittle and ductile phases can offer relatively better resistance. The brittle phase can resist the penetration and the ductile one provides a dampening effect for the load ${ }^{11}$. The disc-on-disc wear machine tested bainitic and pearlitic steel from rail, and it was observed that the increase in hardness at and beneath the surface due to work hardening effects was more significant in bainitic than in pearlitic samples for each testing condition ${ }^{12}$.

Niobium reduces grain size during the recrystallization process. It slows down the retardation of austenite recrystallization in $\mathrm{Nb}$ microalloyed steels, which results from the pinning of austenite grain boundaries by carbonitrides. It is further accepted that these carbides are strain induced 13. The forged wheels manufacturing process has strong recrystallization process associated with high temperature on forging and rolling mill step.

The general alloying elements used to improve the properties are $\mathrm{Nb}, \mathrm{V}$, and Mo from which $\mathrm{Nb}$ is the most important one, making its precipitation behavior during and after austenite conditioning a crucial factor for the final mechanical properties. In fact, the observed high strength-toughness combination is a consequence of finegrained ferrite microstructure of mixed morphologies and precipitation strengthening, mainly on microalloyed steels ${ }^{14}$.

The development of $\mathrm{Nb}$ microalloyed steel, with a mixed microstructure composed of pearlite and bainite that can increase the hardness, yield strength, and toughness is the objective of this study.

\section{Experimental Procedure}

\subsection{Material}

Table 1 shows the chemical composition and austenitic grain size (AGS) of the steels used in this study and two other steels used for comparison; one with $\mathrm{V}$ addition and one with $\mathrm{Nb}$ and Mo additions. All steels were produced at electrical arc furnace (EAF) from carbon (C) steel scrap and vacuum degassed with maximum 2 ppm (parts per million) hydrogen content. The teeming process was conventional that produces round ingots with $390 \mathrm{~mm}$ diameter and 3 meters length. Hot top was applied on all ingots in order to introduce solidification direction. All steels are from the same railroad forged wheel company, using the same process. The AGS is not a requirement for AAR, but it is an important parameter to verify the refinement of the microstructure. The grain size was measured in the wheel rim, according to the American Association for Testing Materials ASTM E 112. Microalloyed steels showed a more refined structure than non-microalloyed steel (class C), which is expected because of the formation of carbonitrides pinning the austenitic grain boundary. The AGS in $\mathrm{Nb}$ steel was smaller than $7 \mathrm{~V}$ and $\mathrm{C}$ steels: 4 ; 6 and $12 \mu \mathrm{m}$, respectively.

Table 1. Chemical composition (weight \%) and austenitic grain size (AGS)

\begin{tabular}{lcccccccccc}
\hline Steel & C & Si & Mn & P & S & V & Nb & Mo & AGS $(\boldsymbol{\mu m})$ & Reference \\
\hline $\mathrm{C}$ & 0.71 & 0.27 & 0.80 & 0.02 & 0.010 & - & - & - & 12 & This study \\
$\mathrm{Nb}$ & 0.72 & 0.31 & 0.78 & 0.02 & 0.008 & - & 0.020 & - & 4 & This study \\
$7 \mathrm{~V}$ & 0.68 & 0.55 & 0.88 & 0.01 & 0.010 & 0.13 & - & - & 6 & Fonseca $^{15}$ \\
7NbMo & 0.63 & 0.31 & 0.82 & 0.01 & 0.002 & - & 0.014 & 0.12 & 10 & Fonseca $^{15}$ \\
\hline
\end{tabular}




\subsection{Heat treatment process}

According to AAR specifications, the wheels must be heat-treated by water quenching on the rim (figure 2), and then tempered for stress relief. One wheel was selected, and the Jominy specimens were extracted in order to simulate the AAR heat treatment on different conditions. The specimens were prepared and subjected to the Jominy test according to ASTM A255 with different heat treatment process conditions. The Jominy specimens of $\mathrm{Nb}$ material were heated in a muffle furnace to different austenitization temperatures. After that, the specimens were tempered in water and then tempered at different temperatures, as shown in table 2 . The hardness was measured at $1 / 16$ " interval. Thermocouples were used on the specimens at austenitization and tempering process in order to control the temperature.

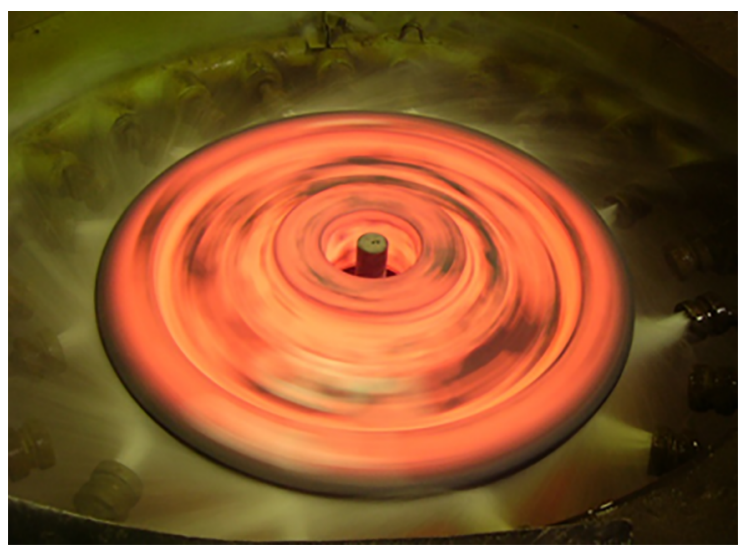

Figure 2. Wheels at heat treatment according to AAR (water quenching)

Table 2. Jominy specimens' temperatures

\begin{tabular}{lcc}
\hline \multirow{2}{*}{ Specimen } & \multicolumn{2}{c}{ Temperatures $\left({ }^{\circ} \mathbf{C}\right)$} \\
\cline { 2 - 3 } & Austenitization & Tempering \\
\hline 1 & 820 & 590 \\
2 & 820 & 540 \\
3 & 820 & 500 \\
4 & 890 & 590 \\
5 & 890 & 540 \\
6 & 890 & 500 \\
\hline
\end{tabular}

\subsection{CCT Diagram}

Dilatometer Type, model $805 \mathrm{~A} / \mathrm{D}$, was used to perform the Continuous Cooling Transformation (CCT) diagram. The specimens ( $\mathrm{Nb}$ material) used had cylindrical shape with $4 \mathrm{~mm}$ external diameter and $10 \mathrm{~mm}$ length. The specimens were heated at $30^{\circ} \mathrm{C} /$ minute rate and at $880^{\circ} \mathrm{C}$; such temperature was held for 5 minutes for austenitization. Then, each specimen was cooled at nine different rates and, when necessary, a helium gas flow was applied. The cooling rates were $0.05,0.3,0.5,1,2,3,5,10,20,30,50$, and 100 ${ }^{\circ} \mathrm{C} / \mathrm{s}$. Each test condition was repeated twice, and type $\mathrm{S}$ thermocouple was used to obtain the data.

\subsection{Hardness test}

Hardness map measurement was performed in accordance with ASTM E-10 (latest revision), with 3,000 Kg load and $10 \mathrm{~mm}$ tungsten sphere on $\mathrm{Nb}$ material. For class $\mathrm{D}$, the hardness range must be 415 - $341 \mathrm{BHN}$.

\subsection{Tensile tests}

Tensile tests were performed at room temperature $(\mathrm{Nb}$ material) and $538^{\circ} \mathrm{C}\left(1,000^{\circ} \mathrm{F}\right)$ with specimens taken from the $\mathrm{Nb}$ steel wheel rim according to the AAR specification M107/208 for class D. The tests were performed in three wheels, with two samples for each wheel. According to AAR standard for tensile tests, the specimen must have at least $1 / 8$ " of the surface wheel tread at the end of specimen head (orange arrows at figure 3). The tensile tests followed the ASTM A 370 standard for room temperature test and ASTM E 21 for hot test $\left(538^{\circ} \mathrm{C}\right.$, according to AAR M107/208 appendix C).

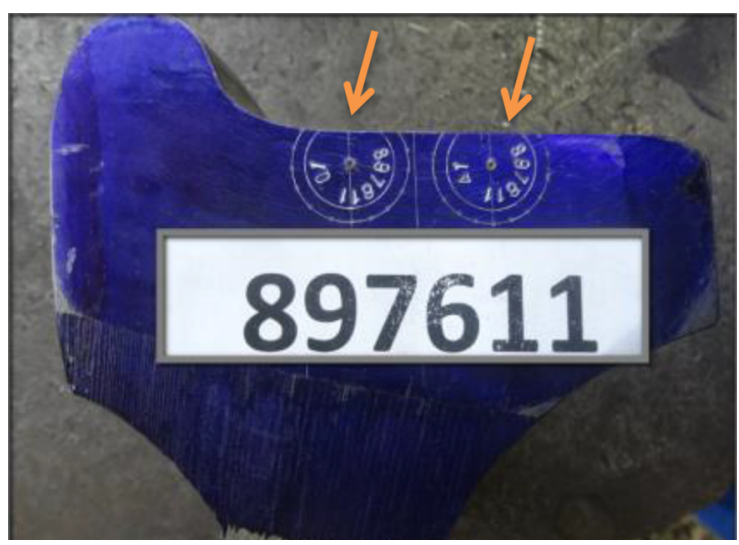

Figure 3. Location of the specimens for tests

\subsection{Fracture test}

The fracture toughness test ( $\mathrm{Nb}$ material) was performed according to the AAR standard M107/208 appendix C, with specimens following ASTM E 399 (figure 3b). Three wheels were used with three samples for each wheel. The minimum value of KIc or KQ must be higher than $40 \mathrm{MPa} \sqrt{\mathrm{m}}$.

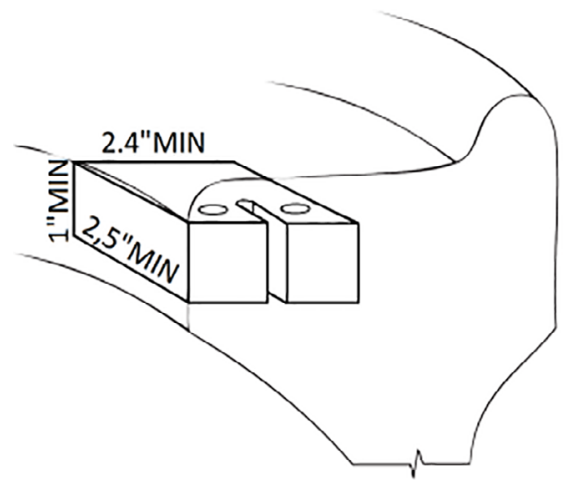

Figure 4. Fracture toughness specimen according to AAR appendix C (2). 


\subsection{Microstructure Analysis}

The microscopy ( $\mathrm{Nb}$ material) was performed on SEM (Scanning Electron Microscope) and TEM (Transmission Electron Microscope) at $\mathrm{Nb}$ steel with the following sample preparations;

SEM samples:

- $\quad$ Polish with diam ond paste;

- Clean with ethanol;

- Dry with air;

- Attack with solution $2 \%$ Nital.

TEM samples:

The specimens were polished by electrolytic process with $75 \%$ ethanol and $25 \%$ perchloric acid solution with 18 Volts tension and 2.5 ampere electric current;

- $\quad 75 \%$ ethanol + perchloric acid solution;

- Washing ethanol + acetone;

- Electrolytic polishing;

- Cleaning in plasma for three minutes before analysis on microscope.

\section{Results and discussion}

\subsection{Jominy test}

Figure 5 shows the Jominy test results according to table 2 . The best result was austenitization at $890{ }^{\circ} \mathrm{C}$ followed by tempering at $500{ }^{\circ} \mathrm{C}$. This process presented uniformity hardness near $43 \mathrm{RC}$ ( $398 \mathrm{HB}$ ) close to maximum hardness of class D wheel specification (415 HB). This heat treatment process was applied for manufacturing the wheel with $\mathrm{Nb}$ steel.

\subsection{CCT Curve}

The CCT diagram obtained for $\mathrm{Nb}$ steel showed the presence of bainite even at very low cooling rate in the range between 0.3 and $2{ }^{\circ} \mathrm{C} / \mathrm{s}$ (figure 6). Fonseca ${ }^{15}$ observed that the minimum cooling rate for bainite to appear on the microstructure was $3^{\circ} \mathrm{C} / \mathrm{s}$ for $7 \mathrm{NbMo}$ steel, $5^{\circ} \mathrm{C} / \mathrm{s}$ for $7 \mathrm{~V}$ steel, and $10^{\circ} \mathrm{C} / \mathrm{s}$ for $\mathrm{C}$ steel.

The cooling rate at the rim during heat treatment changes according to the distance from the wheel tread surface. These rates were obtained previously ${ }^{16}$ :

$5 \mathrm{~mm}: 1.5-3.0^{\circ} \mathrm{C} / \mathrm{s}$

$10 \mathrm{~mm}: 1.5-3.0^{\circ} \mathrm{C} / \mathrm{s}$

$15 \mathrm{~mm}: 1.5-2.5^{\circ} \mathrm{C} / \mathrm{s}$

Therefore, the cooling rate at $10 \mathrm{~mm}$ from tread surface lead to the occurrence of bainite according to the $\mathrm{Nb}$ steel CCT diagram, which corroborates with the metallurgical observation (figures 7 and 8).

\subsection{Size of the austenite grains}

The requirements for AAR class D were not met by $7 \mathrm{NbMo}$ steel, and one reason for it could be the coarser austenitic grain compared to $\mathrm{Nb}$ steel (10 and $4 \mu \mathrm{m}$ for $7 \mathrm{NbMo}$ and $\mathrm{Nb}$, respectively).

\subsection{Hardness map}

AAR standard specifies that the hardness of the wheel rim for class D should be between 321 and $415 \mathrm{BHN}$ in the region up to $25 \mathrm{~mm}$ from finished tread surface. Niobium steel achieves this requirement, as the minimum value on last line is $341 \mathrm{BHN}$ and the maximum value on first line is $415 \mathrm{BHN}$ (figure 7).

\section{HRC Hardness}

Jominy with heat treatment results

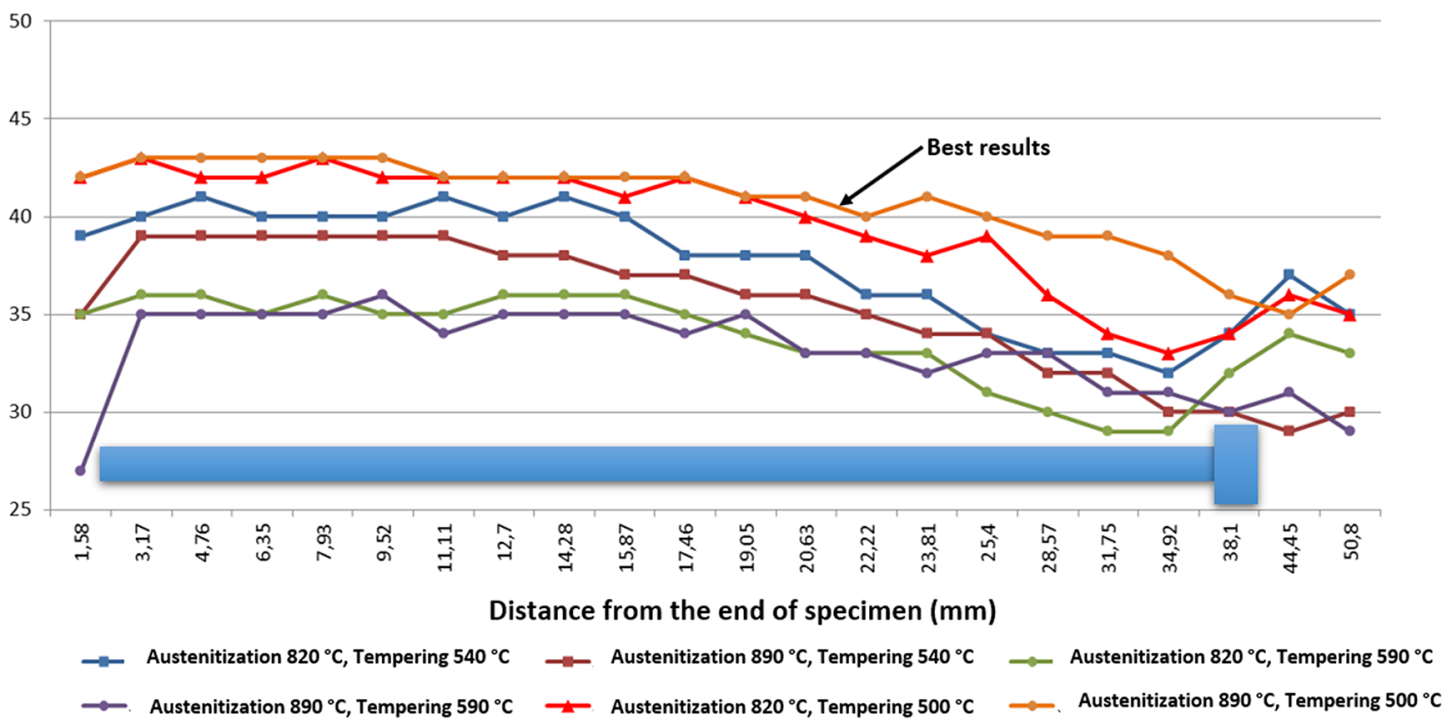

Figure 5. Results of the Jominy test after different heat treatments. 


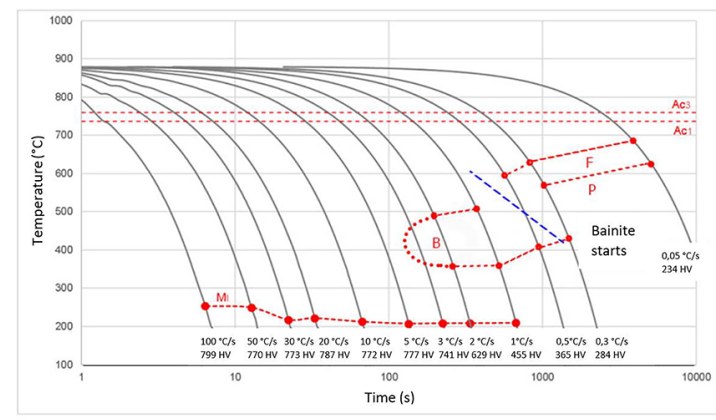

Figure 6. CCT diagram for $\mathrm{Nb}$ microalloyed steel used in this study $(\mathrm{Nb})$

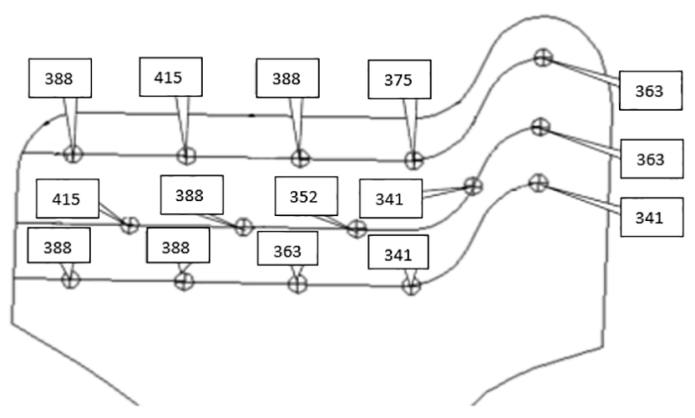

Figure 7. Brinell hardness map of $\mathrm{Nb}$ steel.

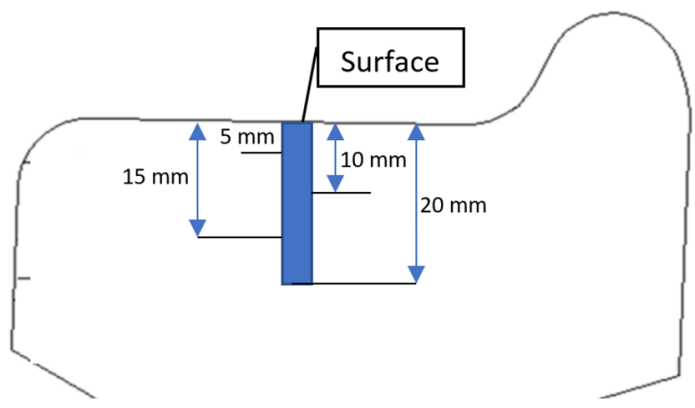

Figure 8. Location of micrographs on the $\mathrm{Nb}$ steel wheel rim.

\subsection{Tensile test}

Table 3 shows the results of tensile test at room temperature $\left(25^{\circ} \mathrm{C}\right)$. The $\mathrm{Nb}$ steel developed in this study achieved the standards required for class D. The yield stress and ultimate tensile stress (UTS) are lower than 7V and $7 \mathrm{NbMo}$, except for elongation and area reduction. The amount of $\mathrm{Nb}$ also differed: $0.020 \%$ weight in this study and $0.014 \%$ weight in $7 \mathrm{NbMo}$ steel. Other factors include the presence of Mo addition on the 7NbMo steel, so it is difficult to understand exactly why $7 \mathrm{NbMo}$ failed in meeting the AAR class D. Table 4 shows the results of tensile test at $538{ }^{\circ} \mathrm{C}$, where it is possible to observe that $7 \mathrm{~V}$ and $\mathrm{Nb}$ steel developed in this study achieved all the standards required for class $\mathrm{D}$; however, $7 \mathrm{NbMo}$ failed in elongation again.

\subsection{Fracture toughness test}

The fracture toughness test results attend the AAR requirement for class $\mathrm{D}$ material, and $\mathrm{Nb}$ steel toughness value is higher than $7 \mathrm{~V}$ and $7 \mathrm{NbMo}$ steels used for comparison. The table 5 shows the average results of 3 specimens:

\subsection{SEM and TEM microstructures}

According to AAR standard, the finished wheel tread should not have martensite. The microstructures produced in this region (figure 6) in the $\mathrm{Nb}$ steel wheel showed bainitic structure near the tread surface followed by fine perlite along the rim (figure 8), which meets the proposal of this development.

The microstructures are according to the CCT diagram and the cooling rate. Bainite is found on the surface when the cooling rate is over $3{ }^{\circ} \mathrm{C} / \mathrm{s}$. At $5 \mathrm{~mm}$ deep and cooling rate between $1.5-3{ }^{\circ} \mathrm{C} / \mathrm{s}$, the $\mathrm{CCT}$ diagram also indicates bainite microstructure. At the same cooling rate and $10 \mathrm{~mm}$ deep, bainite and pearlite are together. The CCT diagram on this cooling rate range is not well defined, so it is possible

Table 3. Results of tensile test and toughness at $25^{\circ} \mathrm{C}$.

\begin{tabular}{lccccc}
\hline Steel & UTS (MPa) & Yield Stress (MPa) & Elongation (\%) & Area Reduction (\%) & Reference \\
\hline $\mathrm{C}$ & $1151 \pm 4$ & $851 \pm 5$ & $13 \pm 1$ & $31 \pm 1$ & This study \\
$\mathrm{Nb}$ & $1151 \pm 10$ & $894 \pm 8$ & $15 \pm 1$ & $40 \pm 1$ & This study \\
$7 \mathrm{~V}$ & $1182 \pm 7$ & $922 \pm 14$ & $14 \pm 1$ & $37 \pm 1$ & Fonseca (15) \\
$7 \mathrm{NbMo}$ & $1205 \pm 11$ & $915 \pm 10$ & $13 \pm 1$ & $32 \pm 2$ & Fonseca (15) \\
$\mathrm{AAR}-\mathrm{D}$ & $>1083$ & $>760$ & $>14$ & $>15$ & AAR (2) \\
\hline
\end{tabular}

Table 4. Results of tensile test at $538^{\circ} \mathrm{C}$.

\begin{tabular}{lccccc}
\hline Steel & UTS (MPa) & Yield Stress (MPa) & Elongation (\%) & Area Reduction (\%) & Reference \\
\hline $\mathrm{Nb}$ & $624 \pm 20$ & $515 \pm 20$ & $24 \pm 2$ & $76 \pm 1$ & This study \\
$7 \mathrm{~V}$ & $582 \pm 21$ & $501 \pm 20$ & $25 \pm 4$ & $92 \pm 1$ & Fonseca (15) \\
$7 \mathrm{NbMo}$ & $574 \pm 15$ & $493 \pm 6$ & $16 \pm 1$ & $72 \pm 2$ & Fonseca $(15)$ \\
$\mathrm{AAR}-\mathrm{D}$ & $>483$ & $>345$ & $>20$ & $>40$ & AAR $(2)$ \\
\hline
\end{tabular}


Table 5. Fracture toughness test results

\begin{tabular}{lcc}
\hline Steel & KIc or KQ $(\mathbf{M P a} \sqrt{\mathrm{m}})$ & Reference \\
\hline $\mathrm{C}$ & $49 \pm 3$ & This study \\
$\mathrm{Nb}$ & $65 \pm 9$ & This study \\
$7 \mathrm{~V}$ & $52 \pm 2$ & Fonseca (15) \\
$7 \mathrm{NbMo}$ & $48 \pm 3$ & Fonseca (15) \\
$\mathrm{AAR}-\mathrm{D}$ & $>40$ & AAR (3) \\
\hline
\end{tabular}

to have both microstructures. The same situation occurs for $15 \mathrm{~mm}$ deep, yet in this case the micrograph shows pearlite microstructure clearly.

At $20 \mathrm{~mm}$ deep, the cooling rate is below $1.5-2.5^{\circ} \mathrm{C} / \mathrm{s}$. The CCT diagram is not well defined once again, but the microstructure indicates pearlite in this area.

TEM images (figure 11) confirmed the mixed microstructure of bainite and perlite in the region at $10 \mathrm{~mm}$ from tread surface.

The TEM images at $10 \mathrm{~mm}$ deep show bainite and pearlite, the same microstructure in figure 9 at this depth.

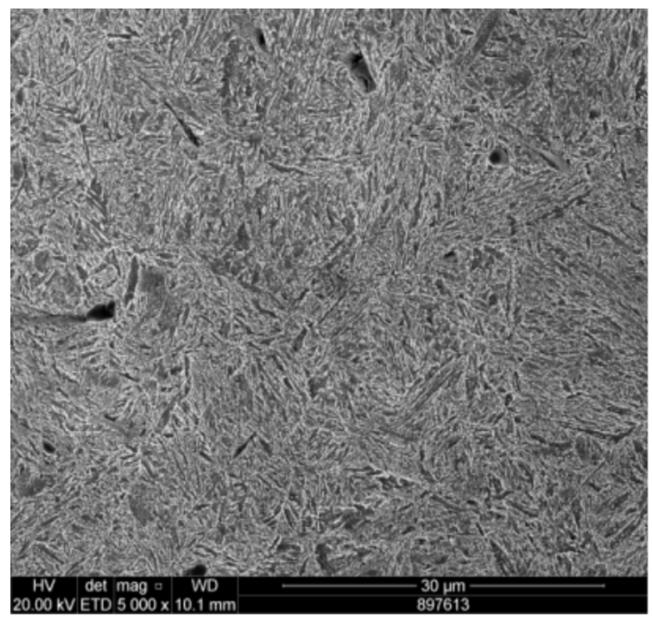

(a)

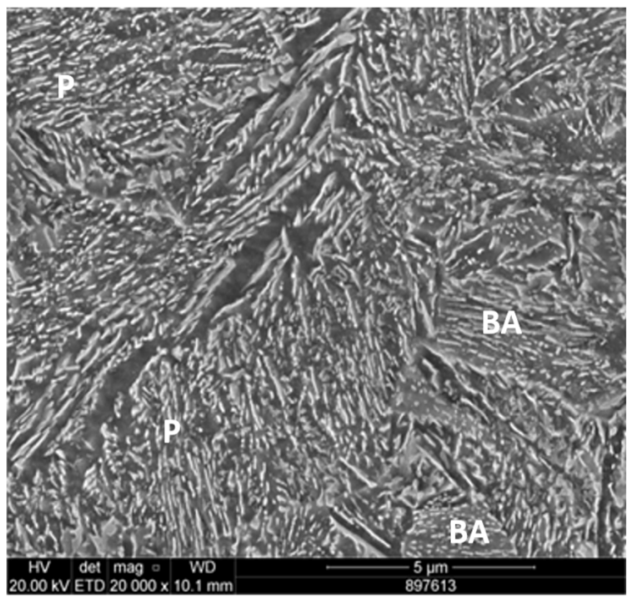

(c)

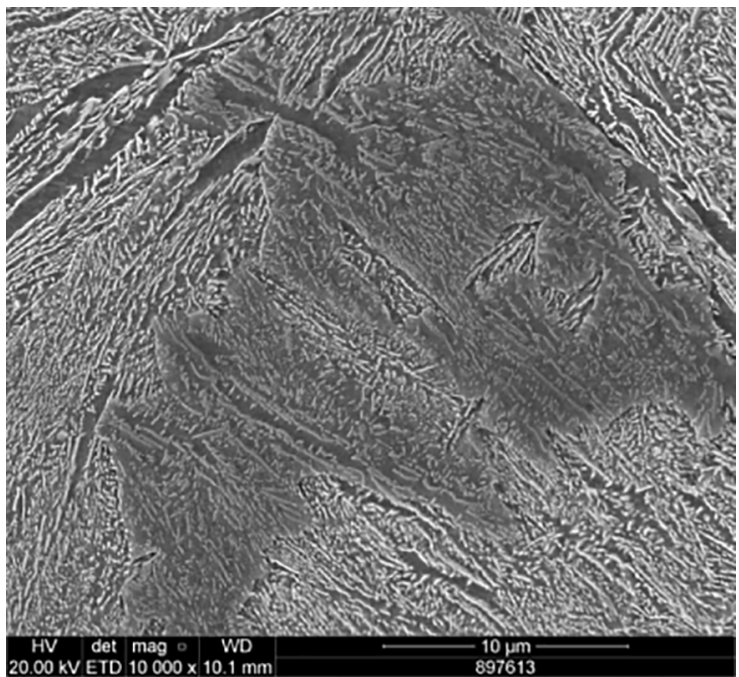

Figure 10. Microstructure of $\mathrm{Nb}$ steel at $20 \mathrm{~mm}$ deep from the surface. SEM. $2 \%$ Nital.

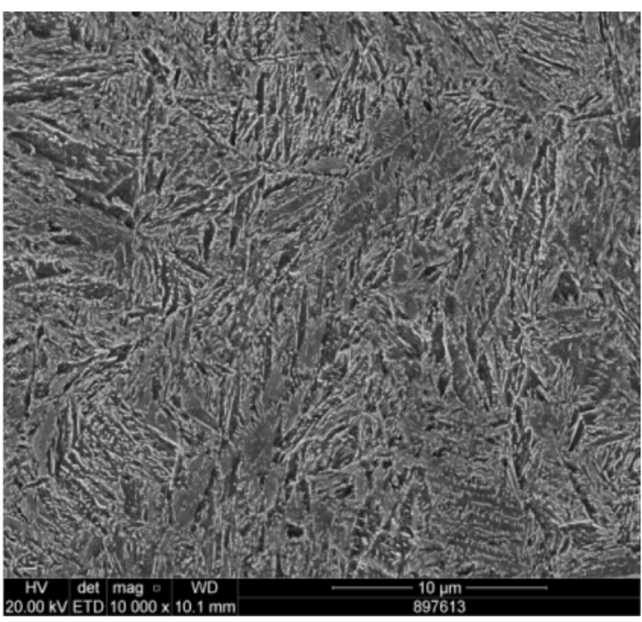

(b)

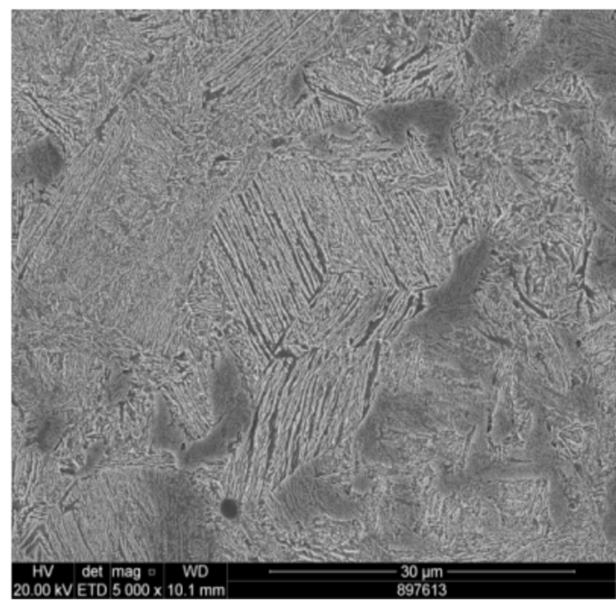

(d)

Figure 9. Microstructure of $\mathrm{Nb}$ steel on tread surface (a), $5 \mathrm{~mm}$ (b), $10 \mathrm{~mm}$ (c), and $15 \mathrm{~mm}$ (d) deep from the surface. SEM with $2 \%$ Nital. $\mathrm{BA}=$ Bainite and $\mathrm{P}=$ Pearlite. 


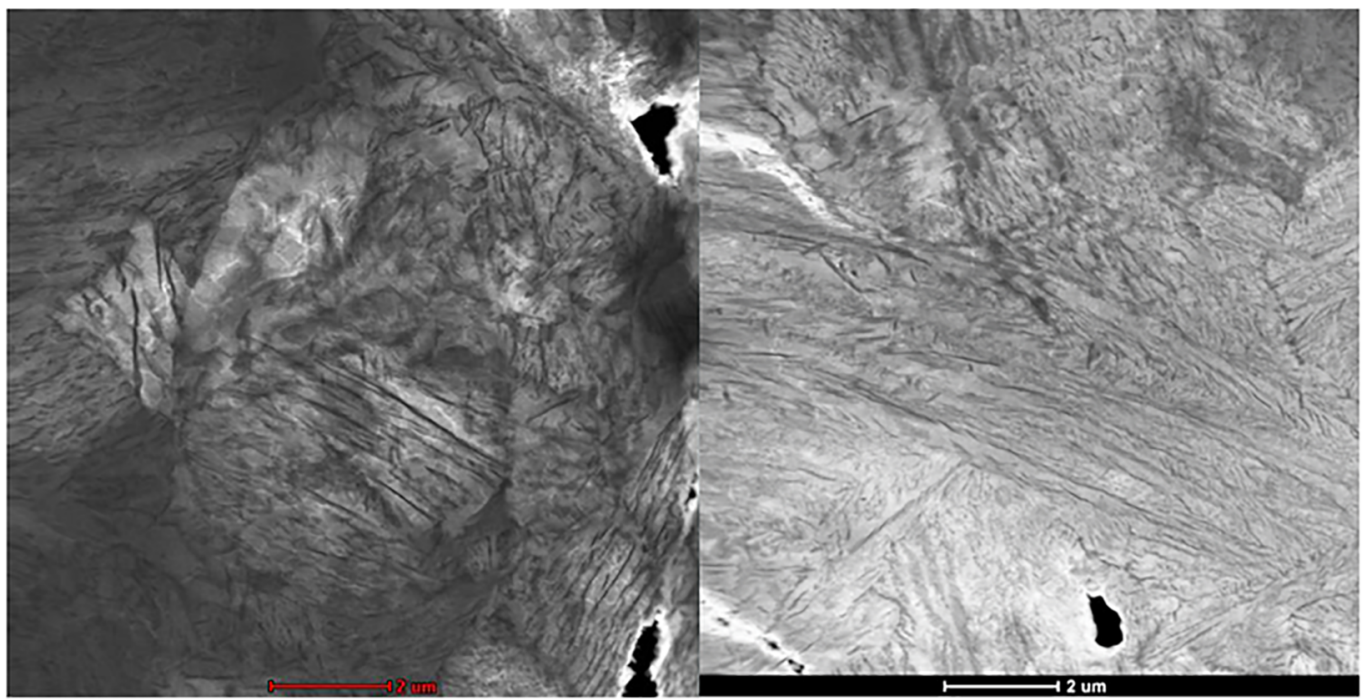

(a)

(b)

Figure 11. Mixed microstructure at $10 \mathrm{~mm}$ from tread surface. a) Pearlite; b) Bainite. TEM.

\section{Conclusions}

The $0.71 \mathrm{C} / 0.27 \mathrm{Si} / 0.80 \mathrm{Mn} / 0.020 \mathrm{Nb}$ steel developed in this study for railroad wheel led to the following conclusions:

- The heat treatment process with austenitization at 890 ${ }^{\circ} \mathrm{C}$ followed by tempering at $500{ }^{\circ} \mathrm{C}$, was the best process to achieve uniformity in hardness. It was near 43 RC (398 HB), close to the maximum value of wheel class $\mathrm{D}$ specification.

- The $\mathrm{Nb}$ microstructure is more refined than the other steels used in this research as the AGS on the wheel rim was observed to be smaller than both $\mathrm{V}$ microalloyed and plain C steels used for comparison: 4, 6, and $12 \mu \mathrm{m}$, respectively. The niobium carbides are very effective to pin the austenite grain boundaries and difficult its growing process.

- The steel achieved the standards required for AAR class $\mathrm{D}$ in all mechanical properties, with fracture toughness higher than the usual V microalloyed steel used for comparison.

- Niobium in solid solution delays the austenite decomposition due its partitioning between ferrite and austenite, increasing the hardenability. Very low cooling rate $\left(0.3^{\circ} \mathrm{C} / \mathrm{s}\right)$ for $\mathrm{Nb}$ steel is enough for bainite formation. This cooling rate to form bainite are much lower than those observed in other steels with similar composition: $3{ }^{\circ} \mathrm{C} / \mathrm{s}$ for $7 \mathrm{NbMo}$ steel, $5^{\circ} \mathrm{C} / \mathrm{s}$ for $7 \mathrm{~V}$ steel, and $10^{\circ} \mathrm{C} / \mathrm{s}$ for plain $\mathrm{C}$ steel.

- The microstructure in the tread region was bainite, and the formation of fine pearlite started $10 \mathrm{~mm}$ below the tread. The microstructure achieved presented high hardness combined with high toughness; thus, this type of steel is ideal for heavy duty railway wheel applications.

\section{Acknowledgments}

Thanks to MWL Laboratory Technicians Peter Alexandre dos Santos and Márcio Quintino, MWL steelworks manager Eng. Carlos Henrique S. Muzzachio, and MWL steelworks consultant Eng. Eduardo Duarte da Silva Pereira, Companhia Brasileira de Metais e Metalurgia (CBMM) and Campinas University (Prof. Dr Paulo R. Mei and Dra Solange T. Fonseca).

\section{References:}

1. Stone D. An interpretative literature review of wheel shelling. In: The American Society of Mechanical Engineers. ASME - 2008 Rail Transportation Division Fall Technical Conference. New York, USA: ASME; 2008. p. 97-103.

2. American Association of Railroads (AAR). M107/208 Section G; 2013.

3. Chattopadhyay C, Sangal S, Mondal K, Garg A. Improved wear resistance of medium carbon microalloyed bainitic steel. Wear. 2012;289:168-179.

4. Oliveira LG. Influência do processo de fabricação no comportamento mecânico de rodas ferroviárias [tese]. Guaratinguetá (SP): UNESP; 2013.

5. Zapata D, Jaramillo J, Toro A. Rolling contact and adhesive wear of bainitic and pearlitic steels in low load regime. Wear. 2011;271(1-2):393-399.

6. Solano-Alvarez W, Pickering EJ, Bhadeshia H. Degradation of nanostructured bainitic steel under rolling contact fatigue. Materials Science \& Engineering: A. 2014;617:156-164.

7. Clayton P, Sawley KJ, Bolton PJ, Pell GM. Wear behavior of bainitic steel. Wear. 1987;120(2):199-220.

8. Rezende AB, Amorim GA, Minicucci DJ, Fonseca ST, Mei PR. Effect of vanadium addition on the surface roughness and fatigue crack propagation in a railroad wheel using twin disc wear test. Defect and Diffusion Forum. 2019;391:66-73. Available from: https://doi.org/10.4028/www.scientific.net/DDF.391.66 
9. Hornaday Junior JR. What kind of rail materials will survive in heavy haul service? (Part 1 of 2). The Journal of Wheel/Rail Interaction. 2014; [cited ANO mês Dia]. Available from: http:// interfacejournal.com/archives/1061

10. Cuddy LJ. The effect of microalloy concentration on the recrystallization austenite during hot deformation. Thermomechanical Processing of Microalloyed Austenite. 1982;129-140.

11. Narayanaswamy B, Hodgson P, Beladi H. Comparisons of the two-body abrasive wear behavior of four different ferrous microstructures with similar hardness levels. Wear. 2016;350351:155-165.

12. Zapata D, Jaramillo J, Toro A. Rolling contact and adhesive wear of bainitic and pearlitic steels in low load regime. Wear. 2011;271(1-2):393-399.
13. Anijdan MSH, Yue S. The necessity of dynamic precipitation for the occurrence of no-recrystalization temperature in $\mathrm{Nb}$ microalloyed steel. Materials Science and Engineering: A. 2011;528(3):803-807.

14. Anijdan SHM, Yue S. The effect of cooling rate, and cool deformation through strain-induced transformation, on microstructural evolution and mechanical properties of microalloyed steels. Metallurgical and Materials Transactions: A. 2012;43(4):1140-1162.

15. Fonseca ST. Efeito de adições de vanádio, nióbio e molibdênio na estrutura e propriedades mecânicas de aços com 0,7\% C utilizados na fabricação de rodas ferroviárias [tese]. Campinas (SP): Faculdade de Engenharia Mecânica-UNICAMP; 2015.

16. MWL Brasil Heat Treatment Report for Freight Car Wheels; 2016. p. 8-9. 